\title{
REGIONAL CONFLICT AND THE CLEAN AIR ACT
}

\author{
Timothy J. Stanton*
}

\begin{abstract}
Economists argue that efficiency criteria should dominate choice in government regulation, but distributional concerns influence policy. The political process determined that high-sulfur coal regions had been hurt by the Clean Air Act and sought to change these effects in the 1977 Amendment to the Act. While other amendments combined promises of environmental change with the attempt to help areas perceived to be hurt by the original Act, one provision, the "local coal amendment" concentrated solely on economic consequences and allowed market intervention for equity concerns. The analysis suggests that the most important determinant of votes on the local coal amendment was the sulfur content of coal deposits in the home state of the Senators. Since most states do not have coal deposits, the votes of Senators from noncoal states became crucial for ultimate passage of the amendment. The emphasis of the analysis was on coalition building efforts.
\end{abstract}

\section{Introduction}

Since Stigler (1971) suggested that economic regulation protects and enhances the regulated parties, numerous authors have applied the stiglerian hypothesis to explain various legislation. Environmental legislation has been investigated especially actively. Two main theories have appeared. One suggests that existing firms influence environmental laws and regulations to decrease total industry output and hence increase profits; the other emphasizes attempts by certain regions of the country to maintain their relative wealth by burdening growing regions with excessive pollution abatement costs (Yandle 1984a). In the former category, Maloney and McCormick (1982) showed that cotton dust standards increased stock prices of affected companies, and Pashigian (1984) reported that small plants were harmed relative to large plants by environmental policies. Descriptions of regional conflicts include the conclusion of Pashigian (1985) that an amendment to the Clean Air Act benefited the high-income, highgrowth states of the Sun Belt; a similar conclusion by Crandall $(1982,1983)$ that economic variables explained Congressional voting on environmental legislation much

*Assistant Professor of Economics, Mount Saint Mary's College. better than did environmental variables; the emphasis by Yandle (1984a) on economic forces shaping the struggle in the choice of either the federal or state level for granting temporary exemptions from sulfur dioxide regulations; and the conclusion of Yandle and Quinn (1984) that employment concerns increasingly affected state expenditures on air pollution abatement as the federal government became more involved in such regulation during the 1970s. While these authors maintained that economic concerns influenced the content and form of environmental regulation, the analyses concentrated on amendments that affected environmental quality as well as economic performance. Although the underlying concerns might have been economic, the purported thrust of the amendments was environmental change. Both economic and environmental interests were intertwined in the amendments (Yandle 1984b). In fact, Kalt and Zupan (1984) questioned the hypothesis that only economic variables are important determinants of legislation and emphasized the importance of ideological variables in explaining voting.

The study reported here extends the previous research by analyzing an amendment to the Clean Air Act that was blatantly economic. The so-called "local coal" amendment made no claim to improve air quality. Its only purpose was to intervene in the market directly to protect high-sulfur coal producers. Environmental ideology did not matter in this vote and the analysis of the vote illustrates more clearly the conflict between high-sulfur coal regions and low-sulfur coal regions. Since fewer than one third of the votes cast on the amendment were from Senators representing significant coal-producing states, however, the coal regions needed support from noncoal states. This report explores the coalition building efforts of the highsulfur-coal-producing states and emphasizes party loyalty and equity criteria as determining factors in influencing the votes of Senators from noncoal states. After Section 2 and 3 summarize the 1970 Clean Air Act and its 1977 Amendment, Section 4 presents a logit model explaining the Senatorial vote on this amendment, and Section 5 summarizes the findings.

\section{The Clean Air Act of 1970}

The 1970 Clean Air Act presented a major attempt to confront the problem if air pollution. This comprehensive federal state forced states to adopt standards at least as 
stringent as federal standards deemed necessary to protect human health and welfare by establishing both National Ambient Air Quality Standards (NAAQS) and New Source Performance Standards (NSPS). The act also charged the newly created Environmental Protection Agency (EPA) with implementing the law.

The NAAQS focused on seven pollutants - sulfur dioxide, particulate matter, nitrogen oxide, hydrocarbons, photochemical oxidants, carbon monoxide and lead - and set standards for each. The Clean Air Act established 236 air-quality regions and designated each as either an attainment area or a nonattainment area. Nonattainment areas were areas in which pollution levels were greater than those established for one or more of the seven pollutants. Under EPA supervision, the states had to develop State Implementation Plans (SIPS) that would force abatement in nonattainment areas to the degree necessary to attain the national standards. Since coal-fired power plants were major emitters of sulfur dioxide $\left(\mathrm{SO}_{2}\right)$, the SIPSs set standards restricting emissions for each plant. These standards ranged from very strict levels of 0.8 pounds of $\mathrm{SO}_{2}$ per million British Thermal Units (BTUs) to nonbinding standards of 16.0 pounds of $\mathrm{SO}_{2}$ per million BTUs (United States Federal Energy Regulatory Commission, 1975).

In addition to regulation of existing sources of pollution, the Clean Air Act required regulation of new sources. The EPA had to establish NSPS that "reflect the degree of emission limitation achievable through application of the best system of emission reduction" (Clean Air Act of 1970, section 111). The EPA translated this into a 1.2 pounds of $\mathrm{SO}_{2}$ per million BTUs emission limit for coal-fired power plants for which construction began after August 17, 1971. For the SIPs and the NSPS, utilities retained the choice of attainment. They could burn coal with a sulfur content sufficiently low that its combustion did not create $\mathrm{SO}_{2}$ emissions greater than the plant standard, or they could install flue-gas desulfurization (FGD) equipment to remove the $\mathrm{SO}_{2}$

immediately after combustion. Essentially, the FGD units, or scrubbers, use the smokestack to maintain a chemical reaction that combines limestone and water with the sulfur to form a sludge. The sludge is then removed and deposited in a sanitary land fill.

Before the implementation of $\mathrm{SO}_{2}$ standards, utilities usually bought locally available coal for steam generation. Since most coal-fired plants were in the industrial Midwest, the Illinois Coal Basin (Illinois, Indiana and western Kentucky) supplied much high-sulfur steam coal. In Appalachia, with its endowment of high-, medium- and low-sulfur reserves, steel companies controlled much of the lower sulfur coal and used it to make coke while the higher sulfur reserves reached the steam markets. The large deposits of low-sulfur coal in the western United States remained largely unexploited. When they were confronted with a choice of $\mathrm{SO}_{2}$ compliance methods, however, most utilities opted for the low-sulfur, or "compliance," coal route. This required paying a premium for the low-sulfur coal, both because of the additional costs of transporting western coal and because of competition with purchasers of Eastern coking coal. Even with this fuel premium, however, coal switching generally represented a lower cost option than installation of unreliable FGD units. Disruptions in the traditional patterns of the steam-coal market appeared in the 1970s as power plants scrambled for low-sulfur coal. High-sulfur producers lost market shares while low-sulfur producers gained steadily.

The 1970 Clean Air Act seemed to reflect a consensus solution to a serious problem and appeared reasonably free of political motives (Navarro 1981). But, in the words of Navarro, the 1977 Amendments to the Clean Air Act were highly political.

"In contrast, the seven-year battle culminating in passage of the 1977 Amendments to the Clean Air Act was marked by all the political divisiveness that had been absent during debate over the 1970 Act. Most of the Amendments were aimed not at solving our national air pollution or energy problems, but rather at attaining an assortment of distributional goals for a powerful coalition of special interest groups, some of which had been disadvantaged by the implementation of the original 1970 Act." (Navarro, 1981).

Regional conflict was very evident in the passage of the 1977 Amendment. Not only did large regional differences in compliance costs and hence in electricity rates cause conflict, changing demand for coal inputs also caused regional strife.

\section{The 1977 Amendment to the Clean Air Act}

Discussion of the Clean Air Act began almost immediately after its passage in 1970. Environmental groups questioned whether the power plant standards were strict enough. Of particular importance to them was interpretation of an ambiguity in the original Act. While nonattainment areas were required to lower their emissions to attainment levels, would attainment areas with very little pollution be permitted to increase emissions to the federal standards? If indeed they would be, the pollution attainment areas of the country would have an advantage over the nonattainment areas in attracting industry. The industrial Northeast and Midwest would suffer while the Sun Belt would benefit. In the Sierra Club v. Ruckelshaus decision, the Supreme Court let stand a lower court ruling that the 
EPA must prevent significant deterioration (PSD) of air quality in areas already meeting ambient air quality standards (Sierra Club v. Ruckelshaus, 4 ERC 1205).

Under the original Act, 1977 was to be the year that the nation would meet air quality standards. When it became clear that these goals would not be met, Congressional subcommittees began considering remedies. They concentrated on both auto emissions and electric power plant emission reforms. PSD provisions were made explicit in the revisions. Further, new source performance standards were revised to require scrubbers for all power plants (Ackerman and Hassler, 1981). Environmentalists strongly supported these Revised New Source Performance Standards (RNSPS) because they believed technology-forcing legislation represented the best method to improve air quality. However, much stricter standards for new sources implied higher electricity costs in growing regions of the country. Crandall (1982) concluded that the higher new-source costs resulting from environmental policy represented a political attempt to prevent the shift of industry from the Northeast and Midwest to the South and West. In his 1983 article Crandall further analyzed the interregional struggle and found that environmental variables were not significant in explaining Congressional and Senatorial voting records whereas economic variables were. Because the high-income, slow-growth states in the Frost Belt supported environmental regulation but the lowincome, high-growth states in the Sun Belt did not, Crandall concluded that pollution abatement laws effectively provided protection for established industries in addition to any environmental protection they might provide.

In addition to the Sun Belt versus Frost Belt strife, another important regional conflict evident in the 1977 Amendment was the battle among coal producers, the major fuel suppliers for the electric power industry. Anticipating the continuing loss of markets from the original Clean Air Act, high-sulfur coal producers promoted measures that enhanced their market share. The low-sulfur coal producers naturally opposed any such provisions because of their negative effects on the market share of low-sulfur coal. In particular, high-sulfur interests combined with environmentalists to support the RNSPS because the mandatory scrubbing provision provided utilities an incentive to seek local coal supplies for new plants (Ackerman and Hassler, 1981).

Competition among suppliers of coal for power generation also manifested itself in another provision of the 1977 Amendment to the Clean Air Act. In June 1977, Howard Metzenbaum, a Democrat from the high-sulfurcoal-producing state of Ohio, introduced an amendment which allowed a governor, the EPA or the President to require the use of local or regional coal to comply with $\mathrm{SO}_{2}$ regulations (White 1981). Compliance schedules could be changed to accommodate the use of local coal. This was another attempt to protect local coal producers in a rapidly changing market. The amendment, which became Section 125 of the Amended Clean Air Act, highlighted the battle between high- and low-sulfur regions, and it became a vehicle for promoting regional coal interests

Unlike the other amendments, however, the local coal provision should not be construed as an environmental vote. Although Section 125 allowed compliance schedules to be changed, use of local coal did not necessarily imply weakening of standards. Standards could be maintained but the local coal option increased compliance costs. The League of Conservation Voters (LCV), a pro-environmental organization that monitors and rates Senatorial and Congressional voting on environmental issues, did not include the local coal amendment as an environmental vote (LCV, 1978). Whereas other amendments to the Clean Air Act influenced both environmental quality and economic activity, the local coal option was a blatant attempt to protect high-sulfur interests from low-sulfur competition. Instead of combining environmental and economic concerns, it allowed interference if the market produced results deemed "unfair." Thus, this amendment represented a purer example of the regional conflict evident in the passage of the 1977 Amendments. Moreover, this conflict was not Sun Belt versus Frost Belt but polarized regions on the basis of their endowment of coal reserves. Classifying regions by coal reserves, however, produces a third region, one that does not have coal. The vote of Senators from this noncoal region became crucial for ultimate passage of the local coal amendment. Kalt and Zupan (1984) stressed the importance of ideology in explaining the vote on other legislation and their suggestion applies to this third block of Senators. For the local coal amendment, however, the ideology was not an environmental ideology but was an ideology based on concepts of fairness.

\section{Analysis of the Political Process}

The Metzenbaum amendment passed the United States Senate 45 to 44 with 11 Senators not voting (Congressional Record, June 10, 1977). Consider the following model for explaining the voting behavior of the Senators:

VOTE $=\mathrm{f}\left(\mathrm{INCOME}, \mathrm{INCOMEGR}, \mathrm{SO}_{2}, \mathrm{TSP}, \mathrm{O}_{3}\right.$, PARTY, SULFLOW, SULFHIGH, LVC)

where: VOTE $=1$ if the Senator votes yes for the local coal provision, $=0$ if the Senator votes no for the local coal provision,

INCOME = per capita personal income in 1979 in the state (Bureau of Economic Analysis), 


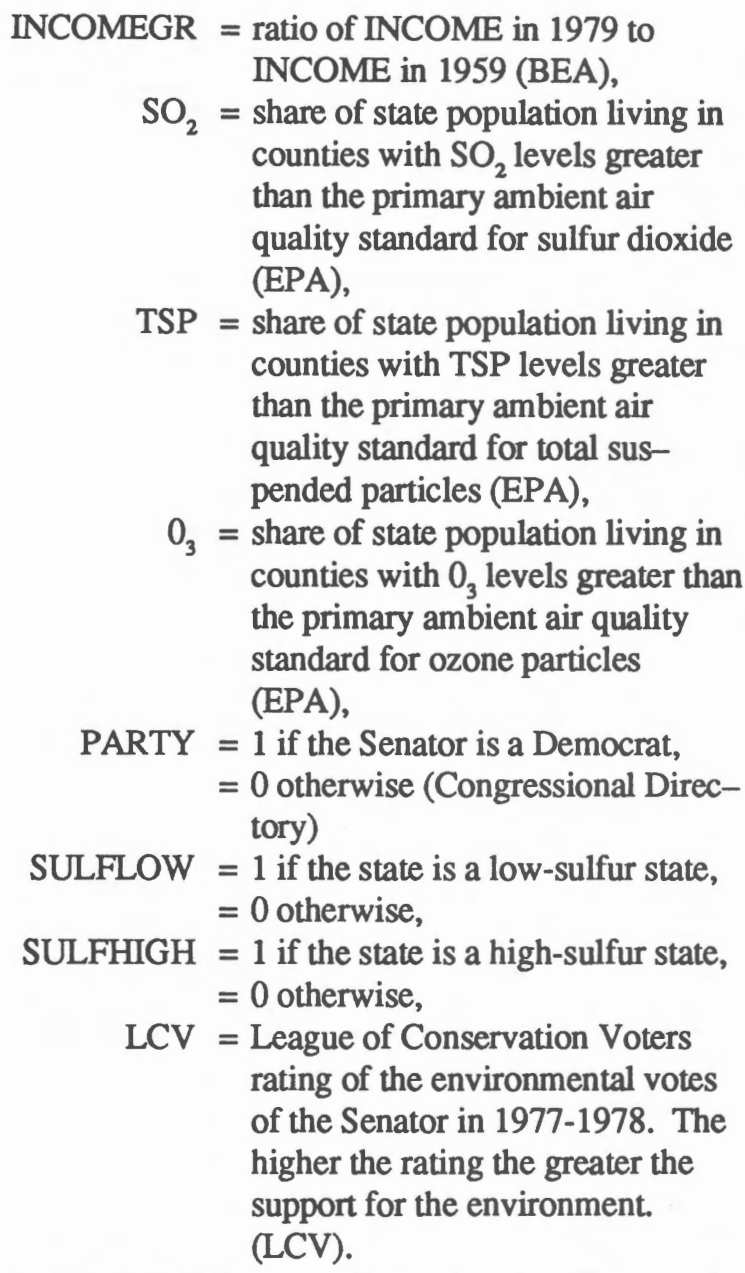

A logit model was used for estimation. Because the dependent variable was binary, either a yes or a no vote, such a model was superior to a linear model (Judge et al. 1985). INCOME, INCOMEGR, $\mathrm{SO}_{2}, \mathrm{TSP}, \mathrm{O}_{3}$ and LCV all were taken from Crandall (1983). VOTE was from the Congressional Record, June 10, 1977. Low-sulfur states unambiguously were Montana, North Dakota, Wyoming, Colorado and Utah. While some coal deposits in Appalachia were low sulfur, the contention was that Senators from those states not only would favor minimal disruptions in coal buying patterns and support legislation to maintain the status quo, but also would fear competition from the western states. Thus, the high-sulfur-coal states were Pennsylvania, Ohio, West Virginia, Virginia, Kentucky, Tennessee, Alabama, Indiana and Illinois.

If Senators from the low-sulfur-coal states opposed the amendment, the coefficient on SULFLOW should be negative. If Senators from states with high-sulfur coal supported the amendment, the coefficient of SULFHIGH should be positive. The coefficients on the three air-quality variables should capture any correlation between VOTE and environmental quality, but no such correlation was expected because the local coal amendment was not an environmental provision. Because the amendment did not affect states with similar incomes or income growth similarly, no correlation was expected between the income measures and the vote. Notice that a Sun Belt versus Frost Belt battle would suggest a positive coefficient on INCOME and a negative coefficient on INCOMEGR. Crandall (1983) found such results. However, this study modeled a specific amendment and hypothesized differences in its support because of differences in the sulfur content of coal in the home states of the voting Senators. No statement was made about the relationship of a yes vote and the level of income or income growth in the state. Some highsulfur coal states had high income growth rates and some did not.

The remaining two variables were meant to capture any ideological differences in support for the amendment. If environmental ideology influenced the vote, $\mathrm{LCV}$ would be expected to be correlated with VOTE. The contention, however, was that the local coal amendment had no environmental content. A priori, even the sign on LCV is questionable. ${ }^{1}$ PARTY should capture any systematic ideological differences between the two political parties and differences in support for Democrat Metzenbaum. Since the coal-producing states had only 28 Senators, only 27 of whom voted, the fate of the local coal amendment depended greatly on Senators from states without substantial coal reserves. Party loyalty and discipline become important determinants of voting in such cases. It was expected that Democrats would be more likely to support an amendment offered by a fellow Democrat than would Republicans.

A further characteristic suggests that Democrats were more likely to support the local coal amendment. To the extent that American political parties can be described as ideological, Democratic Party members generally seem more willing to support legislation that interferes in the market to further distributional concerns. The Senators from the high-sulfur-coal states needed to obtain support from states with no appreciable coal reserves to form a successful coalition. Zeckhauser (1981) suggested that an effective way to formulate policy is to emphasize the winners and losers of the policy. Policymakers are preoccupied with the distributional aspects of policy and wish to prevent large losses to clearly identifiable groups or regions (Zeckhauser 1981). Senators from states without coal deposits could have been swayed to vote for the amendment because of its perceived fairness. With decreased coal demand, high-sulfur regions were experiencing increasing unemployment and legislation that increased labor demand found sympathetic support. Democrats generally are more sympathetic to such equity con- 
cerns and hence, were more likely to support the local coal amendment.

Table 1 presents the results of the maximum likelihood estimation for the complete model and a reduced model. Convergence was achieved for both. In the complete model the coefficient on SULFLOW was negative and significant at the 10 percent level; the coefficient on SULFHIGH was positive and significant at 10 percent. Such signs support the hypothesis that Senators from lowsulfur-coal states opposed the local coal amendment, and Senators from high-sulfur coal states supported it. The positive and significant coefficient on PARTY suggests that Democrats supported the amendment while Republicans did not. This result supports the contention that party discipline and loyalty mattered in passage of this Democratic initiative, or that more Democrats voted for a measure that promised the equity results embodied in the amendment, or some combination of these two. The coefficients of both income variables had positive signs but were not significant. Evidence to support a Sun Belt versus Frost Belt conflict would show a positive and significant coefficient on INCOME and a negative and significant coefficient on INCOMEGR, but the argument here is that the vote on the local coal amendment would not generate results consistent with such a conflict and that the results of Table 1 were expected. The lack of significance of LCV suggests that the contention that this was not an environmental vote is correct. Because this was not an environmental vote, the air pollution quality measures also were not expected to be significant. TSP and $\mathrm{O}_{3}$ indeed were insignificant, but $\mathrm{SO}_{2}$ was positive and significant at the 10 percent level. Senators from states with high $\mathrm{SO}_{2}$ emissions apparently were more likely to support the bill. This correlation likely reflected the fact that states that produced high-sulfur coal also had industrial structures that consumed and burned large quantities of this coal. Several high-sulfur coal states were heavily industrialized and burned local coal for energy needs.

The reduced model of Table 1, with only PARTY, SULFLOW and SULFHIGH included, performed very well in explaining VOTE. All three explanatory variables were of expected sign and were significant. Such results

Table 1

Logit Estimation of the Local Coal Amendment Vote in the Senate

\begin{tabular}{lcc}
\hline Variable & $\begin{array}{c}\text { Complete } \\
\text { Model }\end{array}$ & $\begin{array}{c}\text { Reduced } \\
\text { Model }\end{array}$ \\
\hline CONSTANT & -8.8610 & -1.7303 \\
& $(1.6908)$ & $(3.3235)$ \\
INCOME & 0.0002 & \\
INCOMEGR & $(0.6138)$ & \\
SO ${ }_{2}$ & 1.1876 & \\
TSP & $(1.2261)$ & \\
& 0.0875 & \\
0 3 & $(1.9064)$ & \\
LVC & -0.0139 & \\
& $(0.6840)$ & 2.3724 \\
PARTY & 0.0102 & 4.0159 \\
& $(0.9635)$ & -2.1401 \\
SULFLOW & 0.0099 & $(2.0296)$ \\
& $(0.7777)$ & 2.5364 \\
SULFHIGH & 2.1154 & $(2.9933)$ \\
& $(2.9279)$ & -42.7095 \\
\hline
\end{tabular}

Absolute value of t-statistic in parentheses.

$\mathrm{n}=89$ 
were consistent with the hypothesis that the votes of Senators on the local coal amendment depended on the sulfur content of their home state coal. If their home states had no appreciable coal reserves, party affiliation became critical in determining support for the amendment. Senators from high-sulfur-coal states garnered enough votes for passage of the amendment by invoking calls for party loyalty and stressing the inequities of the original Clean Air Act.

A closer examination of the vote in the Senate reveals some of the coalitions formed in the local coal debate. Table 2 shows a breakdown of the vote. The coal producing states were classified as low-sulfur or highsulfur-coal states, and the votes of the Senators from those states on the local coal amendment were recorded, irrespective of party. The Senators from noncoal states were classified as Democrat or Republican. For each category, a count of yes or no votes is presented. Of the 11 nonvoting Senators, 10 were from noncoal states. Since their constituents did not have a direct economic stake in the local coal amendment, these 10 Senators apparently did not feel compelled to vote. There appears to be no obvious pattern for classifying these Senators.

The behavior of the one nonvoting coal-state Senator, Republican Percy from Illinois, was not consistent with the above explanation of the determinants of voting. Even though the economic interests of his constituents presumably were at stake, Percy did not vote. Equally interesting, one of the two no votes from Senators from the highsulfur coal states was from the other Illinois Senator, Democrat Stevenson. While pressures on Percy to vote yes because of the sulfur content of Illinois coal and to vote no because he was a Republican, the model would have predicted that Stevenson would vote yes because of both his party and the sulfur content of Illinois coal. The Stevenson vote truly was an outlier. Both Senators may have been more concerned about their electricity-consuming constituents in Chicago than about their coal-mining constituents in southern Illinois. Notably, Percy had to face his constituents in an election in 1979, but Stevenson did not face this test until 1981. The latter might have been able to vote his conscience because of the time until reelection while the former might have debated his vote and realizing that he faced reelection shortly, opted for a low profile ${ }^{2}$.

The other two Senators from coal states who voted contrary to the hypothesis, Republican Baker of highsulfur Tennessee with a no vote and Democrat Metcalf of low-sulfur Montana with a yes vote, voted the positions of their parties. Conceivably, coal interests did not have much influence with these Senators, or party loyalty triumphed over economic interests. They did not, however, vote the economic interests of their home state.

It was hypothesized that political party would be the vote determining factor for Senators from the noncoalproducing states. Republicans generally voted the party line. Two of the three Republicans who voted yes, Mathias of Maryland and Brooke of Massachusetts, held liberal views usually associated with the Democratic Party. While 12 Democrats voted no on the amendment, many of them were from the South and West and held conservative views generally associated with the Republican party. There seem to be three exceptions. Both Democratic Senators from Maine and the Democratic Senator from New Jersey voted no. The particular reasons are not evident, but certain nuances peculiar to state politics might have played a role here and in other votes.

\section{Summary}

The 1977 Amendment to the Clean Air Act was a case in which distributional concerns influenced policy. Since the original Clean Air Act and its regulations weakened the advantage that high-sulfur coal had enjoyed and strengthened the position of low-sulfur-coal, high-sulfurcoal regions sought to regain their advantage by supporting

Table 2

Distribution of Votes and Abstention of Senators from Coaland Noncoal-States on the Local Coal Amendment

\begin{tabular}{lrrrr}
\hline \hline Classificatory Item & \multicolumn{4}{c}{ Vote or Nonvote } \\
& Yes & No & Not Voting & All \\
\hline Coal-State Senators & & & & \\
Low-sulfur-coal-states & 1 & 11 & 0 & 12 \\
High-sulfur-coal-states & 15 & 2 & 1 & 18 \\
Noncoal-State Senators & & & 6 & 44 \\
Democrats & 26 & 12 & 4 & 26 \\
Republicans & 3 & 19 & 11 & 100 \\
Totals & 45 & 44 & & \\
\hline
\end{tabular}


provisions intended to encourage utilities to purchase local coal. One proposal of the high-sulfur-coal interests was the local coal amendment. The amendment was devoid of environmental content, and its purpose was blatantly economic. Instead of analyzing an amendment that involved economic and environmental concerns, the purer example of regional economic conflict embodied in the clean air debate was chosen deliberately.

To pass the local coal amendment, however, the high-sulfur forces needed the support of numerous Senators from noncoal states. The obtained this support by emphasizing the losses of a clearly identifiable region and invoking party loyalty. Support for the amendment thus hinged on two things. The Senators from the coal-producing states voted the economic interests of their home states, and the Senators from the noncoal-producing states voted the position of their political parties. The results of a logit analysis were consistent with this hypothesis. Such regional conflict and the attendant coalition building undoubtedly will enter any future debate on additional amendments to the Clean Air Act. The political process will concentrate on equity issues, and efficiency criteria will be sacrificed to achieved distributional goals.

\section{Notes}

IIf the local coal provision was necessary to guarantee passage of the entire 1977 Amendment, the LCV would reflect the environmental ideology manifest in the package of amendments. If the amendment process was a purely economic vote, LCV was an irrelevant variable.

'It should be noted that Percy might not have chosen to abstain but might have had a legitimate reason for missing the vote.

\section{References}

Ackerman, Bruce A. and William T. Hassler, Clean Coal/Dirty Air, Yale University Press, 1981.

Clean Air Act of 1970, section 111 (a) (1), 42 U.S.C. section 1857.

Congressional Record, Volume 123, part 15, June 10, 1977, United States government Printing Office, Washington, D.C., 1977.

Crandall, Robert W., "The Use of Environmental Policy to Reduce Economic Growth in the Sun Belt: The Role of Electric Utility Rates," in Regulatory Reform and Public Utilities, Michael A. Crew, (ed.), Lexington Books, 1982.
Controling Industrial Pollution: The Economics and Politics of Clean Air, The Brookings Institution, Washington, D.C., 1983.

Judge, George G., W.E. Griffiths, R.Carter Hill, Helmut Lutkepohl and Tsoung-Chao Lee, The Theory and Practice of Econometrics, second edition, John Wiley \& Sons, Inc., 1985.

Kalt, Joseph P. and Mark A. Zupan, "Capture and Ideology in the Economic Theory of Politics," The American Economic Review, Volume 74, number 3, June 1984, 279-300.

League of Conservation Voters, "How Congress Voted on Critical Environmental Issues,” Washington, D.C., 1978.

Maloney, Michael T. and Robert McCormick, "A Positive Theory of Environmental Quality Regulation," Journal of Law \& Economics, Volume XXV, April 1982, 99-123.

Navarro, Peter, "The 1977 Clean Air Act Amendments: Energy, Environmental, Economic and Distributional Impacts," Public Policy, Volume 29 number 2, Spring 1981, 121-146.

Pashigian, B. Peter, "The Effect of Environmental Regulation on Optimal Plant Size and Factor Shares," Journal of Law \& Economics, Volume XXVII, April 1984, 1-29.

"Environmental Regulation: Whose Self-Interests Are Being Protected?" Economic Inquiry, Volume XXIII, October 1985, 551-584.

Sierra Club, "Sierra Club v. Ruckelshaus, 4 ERC 1205." National News Report, August, 1979.

Stigler, George J., "The theory of economic regulation," Bell Journal of Economics and Management Science. Spring 1971, 3-21.

United States Federal Energy Regulatory Commission, Cost and Quality of Fuels for Electric Utility Plants, Government Printing Office, Washington, D.C., 1975.

White, Lawrence J., Reforming Regulation: Processes and Problems, Prentice Hall, Inc. Englewood Cliffs, N.J., 1981.

Yandle, Bruce, "Sulfur Dioxide: State Versus Federal Control," The Journal of Energy and Development, Volume 10, number 1, 1984a, 63-72.

"Intertwined Interests, Rent Seeking, and Regulation," Social Science Quarterly, 65(4), 1984b, 1002-1012. and Robert Quinn, "Expenditure on Air Pollution Control Under Federal Regulation," The Joumal of Energy and Development, Volume 10, number 1, 1984, 11-16.

Zeckhauser, Richard, "Preferred Policies When There is a Concern for Probability of Adoption," Journal of Environmental Economics and Management, 8, 1981. 